\section{KOMPETENCIJE I PROFESIONALNI RAZVOJ PROBACIJSKIH SLUŽBENIKA}

SAŽETAK

Zanimanje probacijskog službenika relativno je novo zanimanje u Hrvatskoj. Zemlje zapadnog društva imaju gotovo stoljetnu tradiciju ovog zanimanja, a time i bogata iskustva uspjeha i neuspjeha u obrazovnoj politici prema probacijskim službenicima, što je svakako platforma za učenje o hrvatskom probacijskom sustavu. Ciljevi ovog rada su analizirati i istražiti razine i načine obrazovanja probacijskih službenika na europskom području uz temeljne kompetencije potrebne za njihov rad; istražiti aktualne poteškoće u okviru inozemnih iskustava obrazovanja probacijskih službenika; analizirati elemente dosadašnjeg obrazovanja probacijskih službenika u Hrvatskoj i ponuditi smjernice za cjeloživotno obrazovanje hrvatskih probacijskih službenika. Razina obrazovanja i dodatne edukacije neposredno utječu na kvalitetu rada probacijskih službenika, posredno na njihove stavove, uvjerenja i pristup počiniteljima, te općenito na kvalitetu rada probacijske službe u cjelini. Autori zaključuju da, u odnosu na europsku praksu, hrvatski probacijski službenici aktualno imaju zadovoljavajuću razinu inicijalnih kompetencija i prvih edukacija u kontekstu cjeloživotnog učenja, pri čemu se naglašava važnost očuvanja ovakve prakse, naročito tijekom gospodarske krize.

1 Snježana Maloić, email: snjezana.maloic@pravosudje.hr

2 Doc.dr. sc. Neven Ricijaš, socijalni pedagog, email:neven.ricijas@gmail.com
Pregledni članak

Primljeno: ožujak, 2014.

Prihvaćeno: kolovoz, 2014.

UDK 343.848-057.3

DOI 10.3935/ljsr.v21i2.18

Snježana Maloić ${ }^{1}$

Sektor za probaciju

Uprava za kazneno pravo i

probaciju

Ministarstvo pravosuđa

Neven Ricijaš 2

Edukacijsko-rehabilitacijski

fakultet

Sveučilište u Zagrebu

Ključne riječi:

probacija, probacijski

službenici, kompetencije, obrazovanje, cjeloživotno učenje. 


\section{UVOD}

Dok probacija u Sjedinjenim Američkim Državama i mnogim europskim zemljama ima dugu tradiciju (Kalmthout i Durnescu, 2008.; Maloić i Rajić, 2012.), prve zakonske pretpostavke za obavljanje probacijskih poslova u Hrvatskoj ostvarene su 2009. godine donošenjem prvog Zakona o probaciji. Ovim zakonom ujedno je otvoreno i novo zanimanje u hrvatskom društvu - zanimanje probacijskog službenika (Ricijaš, Maloić i Rajić, 2012.). S obzirom da u Hrvatskoj nisu postojali posebni programi/studiji za probacijske službenike prilikom pripreme ovog zakona, kao temelja za njihovo zapošljavanje, otvorena su pitanja razine i vrste obrazovanja potrebnih za inicijalnu selekciju struka prikladnih za ovo zanimanje. Također se, s obzirom na složenost i zahtjevnost obavljanja probacijskih poslova, postavljalo i pitanje specifičnih znanja i vještina (specifičnih profesionalnih kompetencija) koje bi trebao posjedovati svaki probacijski službenik, odnosno otvorilo se pitanje tema i područja daljnjeg kontinuiranog obrazovanja. Prvi probacijski uredi, a time i probacijski službenici, započeli su s radom 2011. godine (Maloić i Rajić, 2012.), najprije u Zagrebu (Zagreb I i Zagreb II). Potom je uslijedilo otvaranje probacijskih ureda u Osijeku, Požegi, Varaždinu, Bjelovaru, Sisku, Rijeci, Puli, Zadru i Splitu, da bi u siječnju 2013. godine bio otvoren i posljednji, od zasad previđenih dvanaest probacijskih ureda, u Dubrovniku.

Tema obrazovanja probacijskih službenika u Hrvatskoj aktualna je iz dva razloga: (1) nedavno osnivanje probacijske službe u Hrvatskoj i (2) Okvirna odluka Vijeća Europe 2008/947/PUP od 27. studenoga 2008. godine o primjeni načela uzajamnog priznavanja presuda i odluka vezanih uz probaciju s ciljem nadzora izvršavanja probacijskih mjera i alternativnih sankcija. Naime, kako bi se ova odluka mogla provesti u standardnu praksu, države Europske unije (uključujući i Hrvatsku) trebaju razviti zajednička područja prakse i razumijevanja između probacijskih sustava. Jedan od koraka u tom smjeru je i razvoj zajedničkog europskog kurikuluma zaposlenika probacije (Sirdifield, Gardner i Brooker, 2010.; Stout i Canton, 2010.). Sirdifield, Gardner i Brooker (2010.) ističu kako je s tim ciljem nužno razvijati i generičke i lokalne (specifične za države, odnosno regije) elemente kurikuluma, uvažavajući pri tom nacionalne razlike s obzirom na zakonski okvir, funkciju i organizaciju probacije, troškove treninga i slično. Također ističu kako je potrebno razmotriti i motivaciju probacijskih službi za osiguravanjem edukacija prema svojim službenicima, kao i motivaciju službenika da u njima participiraju.

Dakle, pred hrvatskom probacijskom službom bili su i ostaju složeni izazovi definiranja i argumentiranja potrebne inicijalne razine/vrste obrazovanja probacijskih službenika pri zapošljavanju, kao i osmišljavanje i provođenje načina naknadnog obrazovanja probacijskih službenika tijekom njihove profesionalne karijere, u

\section{2 članci}


okviru postojećih iskustava i preporuka na europskom području. Stoga su ciljevi ovog rada analizirati i istražiti razine i načine obrazovanja probacijskih službenika na europskom području uz temeljne kompetencije potrebne za njihov rad; istražiti aktualne poteškoće u okviru inozemnih iskustava obrazovanja probacijskih službenika; analizirati elemente dosadašnjeg obrazovanja probacijskih službenika u Hrvatskoj i ponuditi smjernice za cjeloživotno obrazovanje hrvatskih probacijskih službenika. Kako obim ovog rada ne dozvoljava pojedinačni prikaz načina obrazovanja probacijskih službenika u svim europskim zemljama, koji se po mnogočemu razlikuju, navest će se primjeri pojedinih zemalja, ilustrativni zbog svojih specifičnosti.

\section{VAŽNOST OBRAZOVANJA PROBACIJSKIH SLUŽBENIKA}

lako se obrazovanje probacijskih službenika nameće prvenstveno kao profesionalno i stručno pitanje, ono je ujedno i ekonomsko pitanje, često politički zanimljivo, a ponekad i kontroverzno (Durnescu i Stout, 2011.). Jedan od razloga nedovoljne motiviranosti europskih probacijskih službi za ulaganjem u obrazovanje probacijskih službenika, uz aktualnu gospodarsku krizu, moguće leži i u nedovoljnom znanju i svjesnosti o potencijalnim koristima ulaganja u ovo područje. Naime, probacijski poslovi ne predstavljaju izolirano područje u okviru formalne društvene reakcije na kriminalitet, već su dio šireg sustava i filozofije sankcioniranja počinitelja kaznenih djela. Na europskom prostoru u različitim zemljama postoje različite dominantne penološke doktrine, pa su tako primjerice u Ujedinjenom Kraljevstvu, Estoniji i Bugarskoj dominantniji pristupi usmjereni na upravljanje rizikom i nadzor počinitelja kaznenih djela, dok su, primjerice, u Irskoj, Njemačkoj, Danskoj i Nizozemskoj zastupljeniji pristupi usmjereni prema rehabilitaciji i socijalnoj integraciji počinitelja kaznenih djela (Rentzmann, 2008.; Maloić i Rajić, 2012.; Subramanian i Shames, 2013.; Durnescu, Enengl i Grafl, 2013.).

Posljednjih nekoliko desetljeća istraživanjima se nastoje identificirati najučinkovitije strategije reduciranja kriminalnog recidivizma, što je rezultiralo velikim brojem inozemnih empirijskih istraživanja usmjerenih na paradigmu »što funkcionira (eng. what works), odnosno praksom utemeljenom na dokazima (eng. evidence-based practice) (Latessa, 2006.; Trotter, 2006.; Bonta i Andrews, 2007.; Williams, 2007.; Raynor i Robinson, 2009.; Lovenkamp i sur., 2012.; Lovenkamp i sur., 2013.). Istraživanja postojećih modela supervizije počinitelja kaznenih djela učinkovitijim su dokazala interakciju »licem u lice« s počiniteljima kaznenih djela u okviru dugoročnog procesa promjene ponašanje, u odnosu na pristupe u okviru kojih je usmjerenje samo prema nadzoru pridržavanja obveza i ograničenja počinitelja (Lovenkamp i sur., 2012.). 
U svrhu primjene intervencija čija je učinkovitost dokazana istraživanjima istražuju se i kompetencije probacijskih službenika neophodne za djelotvorno provođenje intervencija. U novije vrijeme počinje se govoriti o konceptu tzv. osnovne korekcijske prakse (eng. core correctional practices) u kojoj su temeljne kompetencije za rad s počiniteljima kaznenih djela kategorizirane u sedam komponenti, koje odgovaraju dvama principima rada (Dowden i Andrews, 2004.; Lovenkamp i sur., 2013.; Andrews i Bonta, 2010., prema Raynor i Ugwudike, 2013.). S ciljem što preglednijeg prikaza, shematski smo prikazali ovaj koncept u tablici 1.

lako postoji niz kritika prakse utemeljene na dokazima, primjerice, da je usmjerena samo na mjerljive ishode te da se ignoriraju čimbenici koje nije lako mjeriti $i$ slično (Trotter, 2006.: 10; Farabee, 2005., prema Byrne i Taxman, 2006.), u izboru načina i metoda rada ipak se prednost daje onima čija je učinkovitost ujedno i objektivizirano/znanstveno potvrđena. Praksa utemeljena na dokazima podrazumijeva da probacijski službenici posjeduju znanje o rezultatima istraživanja u odnosu na različite prakse u njihovom specifičnom području (Trotter, 2006.: 9), kao i da su obučeni u smislu usvajanja znanja i vještina koje će im omogućiti rad u okviru učinkovite prakse. Nedavna empirijska istraživanja pokazala su i potencijalni značaj stavova probacijskih službenika u oblikovanju njihovog ponašanja prema klijentima, kao i u odnosu na ishod za počinitelja kojeg nadziru, odnosno s kojim rade (Lovenkamp i sur., 2013.). Rezultati istraživanja pokazuju da, osim što ima pozitivan učinak na znanje probacijskih službenika, obrazovanje može imati i pozitivan učinak na njihove stavove (Lovenkamp i sur., 2013.). Fulton i sur. (2007., prema Whetzel i sur., 2011.) ističu kako se obrazovanjem mogu modulirati stavovi probacijskih službenika, primjerice, prema većoj usmjerenosti na tretman počinitelja kaznenih djela. $U$ okviru njihovog istraživanja, probacijski službenici koji su bili educirani o procjeni rizika i potreba, učinkovitim intervencijama, upravljanju slučajem temeljem prakse utemeljene na dokazima, bili su daleko više podržavajući prema rehabilitacijskoj funkciji probacije, uz biranje aktivnosti usmjerenih na promjenu ponašanja, a ne samo onih usmjerenih na nadzor počinitelja kaznenog djela. Whetzel i sur. (2011.) ističu kako je ispitivanje, razumijevanje i modificiranje stavova probacijskih službenika, kada je to potrebno, važan korak u usvajanju prakse utemeljene na dokazima, s obzirom da stavovi mogu negativno utjecati na učinke ovakve prakse i rehabilitaciju počinitelja kaznenih djela. Isti autori utvrdili su da probacijski službenici koji su značajnije orijentirani na kažnjavanje češće poduzimaju aktivnosti opoziva probacijskih sankcija i mjera uz preporuku izvršavanja zatvorske kazne, što se nadovezuje na rezultate istraživanja sukladno kojima pristupi usmjereni samo na nadzor počinitelja nisu učinkoviti u reduciranju recidivizma.

\section{4 članci}


Tablica 1. Shematski prikaz principa, komponenti i vještina u okviru osnovne korekcijske prakse (prilagođeno prema Dowden i Andrews, 2004.; Lovenkamp i sur., 2013.; Andrews i Bonta, 2010., prema Raynor i Ugwudike, 2013.)

\begin{tabular}{|c|c|c|}
\hline Princip & Komponenta & Vještine \\
\hline $\begin{array}{l}\text { 1. Princip } \\
\text { odnosa }\end{array}$ & $\begin{array}{l}\text { 1. Uspostavljanje kvalitetnog } \\
\text { profesionalnog odnosa } \\
\text { između probacijskog } \\
\text { službenika i klijenta }\end{array}$ & $\begin{array}{l}\text { - uvažavajući odnos prema počinitelju } \\
\text { - pokazivanje optimizma i empatije } \\
\text { - poticanje suradničkog donošenja } \\
\text { odluka } \\
\text { - prepoznavanje autonomnosti i } \\
\text { individualnosti klijenta }\end{array}$ \\
\hline \multirow{6}{*}{$\begin{array}{l}\text { 2. Princip } \\
\text { strukturiranja }\end{array}$} & $\begin{array}{l}\text { 2. Učinkovito korištenje } \\
\text { autoriteta }\end{array}$ & $\begin{array}{l}\text { - pojašnjavanje pravila i očekivanja } \\
\text { - } \text { korištenje strategija za popuštanje u } \\
\text { otporima, ali koje nisu dominirajuće ili } \\
\text { zlostavljajuće }\end{array}$ \\
\hline & $\begin{array}{l}\text { 3. Prosocijalno modeliranje } \\
\text { i potkrjepljenje/ } \\
\text { osnaživanje }\end{array}$ & $\begin{array}{l}\text { - demonstriranje prosocijalnog } \\
\text { ponašanja } \\
\text { - } \text { korištenje strukturiranog procesa } \\
\text { učenja za razvoj prosocijalnih vještina: } \\
\text { · definiranje vještine koju treba učiti } \\
\text { - modeliranje vještine } \\
\text { - } \text { igranje uloga i korištenje scenarija } \\
\text { - davanje povratne informacije } \\
\text { - } \text { reagiranje na neprihvatljivo ponašanje } \\
\text { negodovanjem i poticanje na } \\
\text { reflektiranje klijenta o verbaliziranom } \\
\text { negodovanju } \\
\text { - reagiranje na poželjno ponašanje } \\
\text { pohvalom te nagrađivanje za takvo } \\
\text { ponašanje }\end{array}$ \\
\hline & 4. Rješavanje problema & $\begin{array}{l}\text { - vođenje klijenta u koracima ispravnog } \\
\text { rješavanja problema }\end{array}$ \\
\hline & $\begin{array}{l}\text { 5. Korištenje resursa u } \\
\text { zajednici }\end{array}$ & $\begin{array}{l}\text { - poznavanje resursa u zajednici koji } \\
\text { mogu odgovoriti na specifične } \\
\text { tretmanske potrebe klijenta }\end{array}$ \\
\hline & $\begin{array}{l}\text { 6. Kognitivno } \\
\text { restrukturiranje }\end{array}$ & $\begin{array}{l}\text { - mijenjanje štetnih misli manje rizičnim } \\
\text { i/ili prosocijalnim načinom razmišljanja }\end{array}$ \\
\hline & 7. Motivacijski intervju & $\begin{array}{ll}\text { - } & \text { razvoj svjesnosti o rizičnosti ponašanja } \\
\text { - } & \text { razvojijačanjemotivacijezapromjenom } \\
& \text { (transfer od nedobrovoljnog klijenta } \\
& \text { prema dobrovoljnom) } \\
\text { - } & \text { jačanje internalne motivacije (od } \\
\text { najčešće eksternalne) prema promjeni } \\
\text { - } & \text { poticanje samoefikasnosti kod klijenta }\end{array}$ \\
\hline
\end{tabular}


Postoji obimna inozemna literatura kojom se naglašava značaj edukacija osoblja o programima koji se temelje na načelima učinkovitih intervencija, a kojima se ističu ključne dimenzije učinkovite realizacije tretmana (Trotter, 2006.; Hussey, 2012.; Lovenkamp i sur., 2013.). Ova istraživanja ukazuju da edukacije i treninzi značajno mogu utjecati na kvalitetu interakcije između probacijskog službenika i počinitelja, kao i na do 25\% manju stopu recidivizma (Trotter, 1996.; Dowden i Andrews, 2004.; Bonta i sur., 2008.). Studija koju je proveo Trotter (1996.) pokazala je da vještine službenika mogu imati snažan utjecaj na stopu povratništva počinitelja kaznenih djela u rasponu od 20 do $70 \%$, što je izniman raspon. Naime, stopa povratništva, mjerena kroz stopu kršenja i stopu ponovnog počinjenja kaznenog djela četiri godine nakon početka supervizije, bila je 25 do $50 \%$ niža kada su, nakon provedenog petodnevnog treninga o načelima prosocijalnog modeliranja i potkrjepljenja/osnaživanja, rješavanja problema i vještina empatije, probacijski službenici koristili načela tzv. prosocijalne supervizije počinitelja. Bonta i sur. (2008.) utvrdili su da je stopa recidivizma počinitelja kaznenih djela koje su nadzirali probacijski službenici educirani u okviru paradigme »što funkcionira« bila $46 \%$, dok je kod počinitelja kaznenih djela koje su nadzirali, o ovoj paradigmi, needucirani službenici ona iznosila $64 \%$.

Prilikom osmišljavanja dodatnih edukacija nije dovoljno u obzir uzeti samo sadržaj programa, već je potrebno voditi računa o tome kako će, i koji sve, ishodi biti ostvareni, te kako će se moći primjenjivati u različitim okruženjima (Sirdifield, Gardner i Brooker, 2010.). Pri tome autori ističu potrebu evaluacije različitih ishoda programa kao što su: (1) opća reakcija i zadovoljstvo edukacijom, (2) utjecaj na stavove i sustav vrijednosti, (3) razina novog znanja i vještina, (4) utjecaj na promjenu u ponašanju/radu, (5) utjecaj na organizacijsku praksu i (5) korisnost edukacije za sustav, klijente i službenike. Naime, kvalitetna i učinkovita skupina edukacija ujedno omogućava i uvođenje visokih standarda prakse (Skinner i Goldhill, 2013.). Važnost takvog pristupa moguće je vidjeti na primjeru francuske probacijske službe. Istraživanje koje je u Francuskoj provela Herzog-Evans (2011.) pokazalo je da probacijski službenici svoje edukacije/treninge, kako one inicijalne na početku rada tako i one tijekom daljnjeg rada, ocjenjuju vrlo negativno. Izjavljuju kako se osjećaju vrlo bespomoćno vezano uz klijente s mentalnim poremećajima ili evidentnim problemima u ponašanju. Bespomoćnim se osjećaju i u radu s klijentima koji imaju probleme ovisnosti o alkoholu i drogama, te istovremeno procjenjuju da je takvih klijenata između 70 i $80 \%$ u populaciji s kojom rade. Takvom osjećaju doprinose i njihova nerealna očekivanja da je totalna apstinencija jedini valjani cilj, pri čemu je on najčešće izvan dosega njihovih klijenata. Edukacija francuskih probacijskih službenika ne temelji se na paradigmi »što funkcionira«, kao ni desistance paradigmi (paradigma procesa prestanka činjenja kaznenih djela, op. autora). Gotovo nikada

\section{6 članci}


ne rade s obitelji počinitelja kaznenog djela (što se djelomice objašnjava i velikim brojem predmeta po jednom probacijskom službeniku), ne uključuju prijatelje i vršnjake u analizu kriminogenih čimbenika, ne pomažu počiniteljima oko financija i raspolaganja novcem, psihološku podršku osiguravaju samo za to motiviranim počiniteljima, a sam proces motiviranja ocjenjuju izuzetno teškim. U okviru svoje edukacije ne dobivaju znanja o tehnikama motivacijskog intervjua, o prosocijalnom modeliranju, kao ni o modelu dobrih života, što su sve važne obrazovne teme implementirane u nekim drugim europskim zemljama. Donekle je paradoksalna situacija da francuski suci optužuju probacijske službenike za traženje opoziva kod vrlo lakih kršenja, te se čini da su suci, u odnosu na probacijske službenike, više rehabilitacijski orijentirani (Herzog-Evans, 2012.).

\section{KOMPETENCIJE PROBACIJSKIH SLUŽBENIKA}

U okviru istraživanja koje je krajem 20. stoljeća u Sjedinjenim Američkim Državama proveo Senna (1976.) tri su područja visokog obrazovanja ocijenjena pogodnima za inicijalno zapošljavanje budućih probacijskih službenika: (1) kriminologija, sociologija, psihologija, edukacija i pedagogija, (2) pravo i socijalni rad, (3) studij cjelovitog kaznenopravnog sustava. Uz uvažavanje svih korisnih znanja i kvalifikacija koja sadrže ova područja, istaknuto je ipak kako svako područje ima i ograničenja u smislu osposobljavanja stručnjaka za probacijski rad. Studije iz prve skupine donekle je bilo teško povezati s neposrednom praksom probacijskog rada. Potom, iako se probacijski službenici donekle bave pravom, studiji prava najčešće nisu uključivali kolegije povezane s uzrocima kriminala i ljudskog ponašanja. Kurikulum studija cjelovitog kaznenopravnog sustava bio je usmjeren na razumijevanje kriminalnog ponašanja i kaznenopravnog sustava, međutim i ovaj je studij nudio malo vještina potrebnih za neposredan rad s počiniteljem kaznenih djela. Povijesno gledajući, studij socijalnog rada dugo se smatrao najprikladnijim za probacijski rad. Ipak, krajem 20. stoljeća u pojedinim se državama (primjerice, Engleska i Wales) sve više isticalo da i u okviru ovih studija nedostaju znanja potrebna probacijskim službenicima, kao što su teorijska znanja o kriminalu, o radu drugih agencija u okviru kaznenopravnog sustava i o različitim filozofijama kažnjavanja (Nellis, 1992.; Persson i Svensson, 2011.).

Pristupu kroz socijalni rad se, iako često neopravdano, zamjerala prevelika usmjerenost na počinitelja kaznenog djela i njegove potrebe, uz istovremeno "zanemarivanje« potreba i prava žrtava te sigurnosti zajednice. Stoga se u pojedinim državama naglasak sve više počeo stavljati upravo na sigurnost zajednice i upravljanje rizikom. Također se zamjeralo da je "politički previše lijevo«, da službenicima ne osigurava »specifične probacijske vještine«, kao i da tako educirani probacijski 
službenici nisu dovoljno »čvrsti« (Raynor i Ugwudike, 2013.). S vremenom se i u okviru usmjerenja na sigurnost zajednice i upravljanje rizikom sve više postavlja pitanje što je zapravo zadatak probacijskih službi: (1) kratkoročno upravljanje rizikom počinitelja kaznenih djela u zajednici ili (2) dugoročna promjena ponašanja u svrhu smanjenja povratništva (Paparozzi i Hinzman, 2005., prema Whetzel i sur., 2011.). Time se ponovno aktualiziralo pitanje čemu dati prednost - socijalnom radu koji je bio usmjeren na počinitelja ili pristupu usmjerenom na sigurnost zajednice i provedbu zakona (eng. public safety and law enforcement). Danas se sve više zagovara uravnoteženi pristup (eng. balanced approach) u okviru kojeg se željeni ciljevi vezani uz zaštitu zajednice ostvaruju kroz strategije upravljanja slučajem, a koje uključuju kombinaciju aktivnosti u okviru provedbe zakona i aktivnosti socijalnog rada (Whetzel i sur., 2011.). Ispitujući stavove probacijskih službenika, Paparozzi (1994., prema Whetzel i sur., 2011.) je utvrdio kako klijenti probacijskih službenika koji su usmjereni na socijalni rad imaju značajno više stope novog uhićivanja, a niže stope tehničkih kršenja; klijenti probacijskih službenika koji su bili usmjereni na striktnu provedbu zakona imali su značajno više stope tehničkih kršenja $i$ niže stope novog uhićivanja; klijenti probacijskih službenika koji su radili u okviru uravnoteženog pristupa imali su niske stope tehničkog kršenja i novih uhićivanja. Istraživanje koje su proveli Raynor i Ugwudike (2013.) pokazalo je da su gotovo svi probacijski službenici imali visoke rezultate u području stvaranja dobrog odnosa s počiniteljem kaznenog djela, što se djelomice može objasniti činjenicom da je istraživanje provedeno u probacijskoj službi na otoku Jerseyju, koja svoj rad temelji na načelima socijalnog rada. Ipak, rezultati su ukazali da su klijenti probacijskih službenika obrazovanih i usmjerenih na korištenje vještina prosocijalnog modeliranja, rješavanja problema i kognitivnog restrukturiranja, postizali više promjena u svojim stavovima i ponašanju, te su imali manju stopu recidivizma.

U Sjevernoj Irskoj i nadalje je aktualan stav kako je najprikladnija edukacija za probacijske službenike studij socijalnog rada (Doran i Cooper, 2008.). Smatra se da se tako najbolje usvajaju znanja i vještine potrebne za profesionalnu procjenu osoba sa složenim problemima u ponašanju i u kompleksnim situacijama, planiranje prikladnih intervencija u svrhu promoviranja pozitivne promjene, vrednovanje učinkovitosti intervencija i postizanje ravnoteže između potreba pojedinca i potreba zajednice. Za zapošljavanje u Švedskoj probacijskoj službi potrebno je imati sveučilišnu razinu obrazovanja, poželjno prvostupnika socijalnog rada, iako je moguće zaposliti i nekoga iz područja odgojnih ili pravnih znanosti (Persson i Svensson, 2011.). Za sve probacijske službenike obavezna je dodatna edukacija u trajanju od 28 tjedana (kombinacija usvajanja teorijskog znanja i praktičnog treninga). Tek nakon ove edukacije, probacijski službenici polaze različite specijalizi-

\section{8 članci}


rane edukacije/treninge, primjerice, vezane uz korištenje instrumenata procjene ili praktično provođenje specifičnih programa.

Mogli bismo reći da su, osim u Švedskoj, probacijski službenici skloniji intervencijama karakterističnima za socijalni rad i u nekim drugim zemljama, kao primjerice u Njemačkoj i Škotskoj. S druge strane, probacijski službenici iz Engleske i Walesa naginju pristupima kao što je aktuarska procjena rizika i kriminogenih potreba i upravljanje rizikom (Durnescu i Stout, 2011.; Maloić i Rajić, 2012.). U Francuskoj se probacijske službenike odabire kroz nacionalni ispit i potom ih se upisuje u tzv. Nacionalnu školu zatvorskog/pravosudnog sustava (eng. National Penitentiary Administration School - ENAP), a uslijed nedostatka stručnjaka iz područja društvenih znanosti ili kriminologije, značajno se zapošljavaju i pravnici, pri čemu edukacija traje godinu dana, i ne obuhvaća praksu utemeljenu na dokazima, kao ni praktične tehnike rada (Herzog-Evans, 2011.).

U Engleskoj i Walesu od 1998. godine postoji poseban studij obrazovanja probacijskih službenika (eng. Diploma in Probation Studies - DipPS, od 2010. godine Probation Qualification Framework - PQF). Razvoj ovog studija, tj. odvajanje obrazovanja probacijskih službenika od dotad postojećeg u okviru socijalnog rada, izazvao je velike rasprave i dileme. Naime, engleski probacijski službenici sada se više educiraju u smjeru upravljanja rizikom i zaštite zajednice, a manje u smjeru rehabilitacije i socijalne dobrobiti počinitelja kaznenog djela (Faulkner, 2007., prema Davies i Durrance, 2009.). Zbog razlika u načinu obrazovanja (razini i sadržaju), probacijski službenici koji su svoju edukaciju završili u Engleskoj i Walesu nisu kvalificirani za rad u Sjevernoj Irskoj ili Škotskoj (Stout i Thompson, 2008., prema Stout i Canton, 2010.).

Bracken (2003.) je proveo istraživanje procjene važnosti profesionalnih kompetencija probacijskih službenika neophodnih za rad u Kanadi i Ujedinjenom Kraljevstvu. Unatoč različitim političkim i strukturalnim kontekstima, probacijski službenici iz oba uzorka generalno su se složili oko četiri najvažnije vještine: (1) vještine interpersonalne komunikacije, (2) vještine vođenja razgovora, (3) suočavanje i nošenje s osjećajima počinitelja, (4) poznavanje resursa u zajednici. Tvrdnje koje se odnose na znanja općenito su bile niže rangirane u odnosu na tvrdnje koje su uključivale vještine, a najniže je rangirano znanje iz kaznenog prava i psihologije. Tijekom analize rezultata, autor ističe kako nije moguće odrediti do koje mjere probacijski službenici biraju određena znanja i vještine zato što službena politika organizacije kaže da su važna ili nevažna, a u kojoj mjeri sami službenici temeljem svojeg vlastitog rada i iskustva vjeruju da su važna za rad s počiniteljima kaznenih djela. Slični rezultati o višem rangiranju vještina u odnosu na znanja dobiveni su i u hrvatskom istraživanju procjene važnosti, te samoprocjeni usvojenosti, profesionalnih kompetencija socijalnih pedagoga u različitim sustavima (Dodig i Ricijaš, 
2011.). U odnosu na konkretne teme, rezultati navedenog istraživanja pokazuju kako socijalni pedagozi zaposleni u sustavu pravosuđa najvažnijim za svoj profesionalni rad procjenjuju vještine individualnog i grupnog rada s klijentima, a zatim znanja iz kriminologije i penologije, kao i opća znanja o poremećajima u ponašanju.

U suvremenoj literaturi sve se više ističe važnost integriranog pristupa, u smislu omogućavanja razvoja kritičke i reflektivne primjene vještina, kao i neophodna važnost šireg znanja (Knight i Stout, 2009.). Profesionalno bi znanje probacijskih službenika svakako trebalo uključivati i razumijevanje složenih političkih, ekonomskih i socijalnih procesa koji utječu na činjenje kaznenih djela, načina kažnjavanja te načina pomaganja u procesu prestanka činjenja kaznenih djela. Dakle, trebaju posjedovati šire razumijevanje kriminogenih čimbenika (individualnih i socijalnih), kao i vještine koje se mogu prilagođavati potrebama pojedinaca (Skinner i Goldhill, 2013.).

U okviru integriranog pristupa probacijskom radu vrlo su važne edukacije koje obučavaju probacijske službenike za primjenu različitih instrumenata procjene (Oleson i sur., 2011.). Za točnu i uravnoteženu procjenu rizika i potreba potrebno je prikupiti i analizirati složene informacije, uz šire i dublje razumijevanje osobnih i situacijskih čimbenika koji mogu doprinijeti počinjenju kaznenog djela (Skinner i Goldhill, 2013.). Nadalje, probacijski službenici rade s klijentima koji nisu sami odabrali intervencije koje se prema njima primjenjuju, a koji mogu i aktivno osporavati potrebu i opravdanost pružanja te usluge, te je potrebno prevladati inicijalni otpor i imati znanja za to, što znači da probacijski službenici trebaju posjedovati znanja i vještine koje će im omogućiti motiviranje počinitelja kaznih djela za vlastiti angažman u promjeni ponašanja i stila života (Elliot, 2002.; Trotter, 2006.: 2; Walters i sur., 2007.; Norton, 2012.; Skinner i Goldhill, 2013.). Po dolasku u probacijsku službu, novi službenici najčešće nemaju znanja i iskustva za učinkovit rad s osobama koje imaju probleme mentalnog zdravlja, te su nužni treninzi osposobljavanja za prepoznavanje problema, prepoznavanje lokalnih resursa i povezivanje takvih osuđenika s dionicima u zajednici (Latessa, 1996.; Slate i sur., 2003.; Slate i sur., 2004.; Brooker i Sirdifield, 2009.). S obzirom na veliku zastupljenost ovisnika o alkoholu i drogama u probacijskoj populaciji, probacijski službenici trebaju raspolagati različitim specifičnim znanjima i vještinama rada s ovom populacijom (Falkin, Strauss i Bohen, 1999.; Torres i Latta, 2000.; Maloić i Mažar, 2013.), naročito s obzirom na rezultate istraživanja koji ukazuju da ovakav rad može imati značajan utjecaj na smanjenje kriminalnog recidivizma (Maloić, Mažar i Jandrić Nišević, 2013.). U okviru probacije posebno su zahtjevna skupina počinitelji seksualnih delikata, za rad s kojima su probacijskim službenicima također nužni dodatni treninzi (Jenuwine, Simmons i Swies, 2003.), kao i počinitelji obiteljskog nasilja te počinitelji s intelektualnim teškoćama (Reddick i Chapin, 1999.; Morran, 2008.).

\section{0 članci}


Specifična znanja pokazala su se potrebnima i kod različitih faza kaznenog postupka, izvršavanja kazne zatvora ili kod uvjetnog otpusta (Seiter, 2002.). Određene vještine probacijskim su službenicima potrebne i u neposrednoj suradnji sa sucima i državnim odvjetnicima. Primjerice, u okviru istraživanja koje su proveli MacDonald i Baroody-Hart (1999.), suci su naglasili kako im je vrlo važna neposredna i informirana komunikacija u sudnici, pri čemu im je bitno da probacijski službenik govori jasno te da na adekvatan način artikulira i argumentira svoje mišljene. Dobra komunikacija sa sucima naročito je važna u situacijama neprimjerenog ponašanja počinitelja kaznenog djela u okviru probacije (Cox, Bantley i Roscoe, 2005.). Pri tome se posebno važnim segmentom rada probacijskih službenika pokazuju formalna (tehnička) kršenja uvjeta nadzora (Burke, Grelb i Horowitz, 2007.; Maloić, Mažar i Jandrić, 2013.) te donošenje adekvatnih stručnih odluka i prijedloga, a za što je svakako nužno dodatno educirati probacijske službenike (Sieh, 2003.; Jones i Kerbs, 2007.; Hanser, 2010.: 204). Cox, Bantley i Newton (2010.) ističu kako primjena određenih intervencijskih programa može imati značajan učinak na smanjivanje formalnih kršenja uvjeta (najmanje za 20\%).

Neosporna je činjenica kako je osmišljavanje europskog probacijskog kurikuluma izazovan posao, te da on mora integrirati složene kriminogene rizike/potrebe populacije s kojom rade probacijski službenici, sumirati ključne generičke i specifične kompetencije, a opet uvažavati nacionalne različitosti i perspektive, pri čemu su identificirane sljedeće prijetnje i prilike/mogućnosti (Kalmthout i Durnescu, 2008.: 19-20; Stout i Canton, 2010; Maloić i Rajić, 2012.).

Dosad su kao glavne prijetnje prepoznate:

(1) dojam kako je osmišljavanje ovakvog kurikuluma vrlo nisko na listi prioriteta europskih probacijskih službi

(2) različiti trendovi u europskim probacijskim službama - socijalni rad, zaštita zajednice, upravljanje rizikom

(3) velike različitosti provođenja edukacija probacijskih službenika s obzirom na strukturu, disciplinu, lokaciju i općenito načine organizacije.

Kao prilike/mogućnosti koje pomažu u ovom procesu moguće je istaknuti:

(1) europske probacijske službe donekle postaju sve sličnije s obzirom na različite EU-projekte i razmjenu iskustava i instrumenata

(2) iako se neke probacijske aktivnosti provode u samo nekoliko zemalja, većina aktivnosti je zajednička svim zemljama, a velik broj ovih aktivnosti odnosi se na različite oblike supervizije počinitelja ili pisanja izvješća

(3) promišljanja o općim vještinama koje bi mogle biti primjenjive u različitim aktivnostima i u okviru različitih probacijskih filozofija. 
Europska grupa za probacijski kurikulum (eng. European Probation Curriculum Group) provela je 2010. godine istraživanje različitih probacijskih kurikuluma (eng. probation curricula) u europskim zemljama (Durnescu i Stout, 2011.). Temeljem ranijih istraživanja i nakon konzultacija sa specijalistima iz različitih zemalja, istaknuto je sljedećih 7 ključnih kompetencija neophodnih za rad probacijskih službenika:

(1) kreiranje i razvoj profesionalnog odnosa

(2) komuniciranje s dobrovoljnim i nedobrovoljnim klijentima

(3) procjena ponašanja počinitelja kaznenog djela

(4) planiranje i pružanje učinkovitih intervencija

(5) rad s raznolikim obilježjima klijenata (eng. work with diversity)

(6) rad s drugim agencijama (službama i dionicima)

(7) pisanje relevantnih izvješća.

Europskim probacijskim pravilima (eng. European Probation Rules) koja je u siječnju 2010. godine prihvatio Odbor ministara Vijeća Europe, određen je temeljni okvir edukacije službenika probacije (pravila 23-28):

(1) svom osoblju treba omogućiti odgovarajuću razinu edukacije sukladno njihovoj ulozi i razini profesionalne odgovornosti

(2) inicijalna edukacija treba biti osigurana za cjelokupno osoblje, uz procjenu i potvrdu usvojenih kompetencija i kvalifikacija

(3) osim na početku, stručno usavršavanje treba biti omogućeno probacijskim službenicima tijekom cijele karijere (koncept cjeloživotnog učenja, op. autora)

(4) edukacija treba osposobiti osoblje za stručne procjene i odluke unutar pravnog i etičkih okvira, okvira organizacijske politike, suvremenih metodoloških standarda i kodeksa ponašanja

(5) trebaju postojati specijalizirane edukacije dostupne za osoblje koje radi s najzahtjevnijim počiniteljima.

\section{RAZINE I MODELI OBRAZOVANJA PROBACIJSKIH SLUŽBENIKA U EUROPSKOM PROSTORU}

Krajem prošlog stoljeća u Sjedinjenim Američkim Državama, uz koje se u najvećoj mjeri vežu začeci probacije, manje od $30 \%$ probacijskih službenika imalo je sveučilišnu diplomu (Senna, 1976.). S vremenom, i na američkom i na Hrvatskoj bližem europskom području teži se što višoj inicijalnoj razini obrazovanja probacijskih službenika, kao i njihovom kontinuiranom stručnom usavršavanju i/ili specijalizaciji.

\section{2 članci}


U razinama i načinima obrazovanja službenika probacije među europskim državama postoje sličnosti i razlike (Kalmthout i Durnescu, 2008.). Vezano uz ranije obrazovanje, od probacijskih službenika se u pravilu traži da posjeduju barem diplomu preddiplomskog studija ili diplomu socijalnog rada (primjerice u Austriji, Njemačkoj, Nizozemskoj, Norveškoj, Italiji, Švedskoj), ili srodnih društvenih područja kao što su socijalna pedagogija, psihologija, pravo, teologija i slično. U većini europskih država, uvodne edukacije prati godinu dana mentoriranog rada, s ciljem osiguravanja adekvatnog izvršavanja posla. Nastavno na uvodni trening, probacijske službe svojim zaposlenicima omogućavaju i cjeloživotno usavršavanje vezano uz specijaliziranje ili nove teme (primjerice, zlouporaba droge i alkohola, rad za opće dobro na slobodi, itd.). Neke od ovih edukacija odvijaju se u okviru ministarstva pravosuđa (na primjer, Francuska, Italija, Litva, Norveška), dok neke na sveučilištima kao diplomski, specijalistički ili poslijediplomski studijski programi. Drugi, uglavnom kraći, oblici treninga odvijaju se u okviru probacijskog sustava.

Istraživanja pokazuju da radionice u svrhu usvajanja novih vještina nisu same po sebi dovoljne, već da su potrebni kontinuirani trening i vođenje (Lovenkamp i sur., 2012.) što oslikava složene potrebe probacijskih službenika. Joyce i Showers (2002., prema Lovenkamp i sur., 2012.) ističu da se nakon provedenog obrazovanja koje obuhvaća teoriju, vježbanje i modeliranje vještina, igranje uloga uz davanje povratnih informacija, na radnom mjestu koristi samo $5 \%$ novih vještina. Međutim, ukoliko se trening i vođenje nastave na samom poslu, neposredno dok probacijski službenici rade s korisnicima, korištenje svih znanja i vještina raste i do 95\%. Tada službenici mogu postavljati pitanja koja su im ostala nejasna nakon provedene edukacije te bolje razumjeti kako bi se određene vještine mogle zaista neposredno koristiti s klijentima u svakodnevnom radu. Naknadno su Lovenkamp i sur. (2012.) u svojem istraživanju potvrdili ovakve trendove.

Stout i Canton (2010.) ističu kako je danas općenito prihvaćeno stajalište o nužnosti barem preddiplomske sveučilišne diplome probacijskih službenika. U Belgiji, Danskoj i Njemačkoj probacijski službenici počinju raditi nakon završenog preddiplomskog studija (razina prvostupnika), a dodatne profesionalne vještine stječu u okviru usavršavanja tijekom rada (cjeloživotno učenje). U Nizozemskoj te Engleskoj i Walesu probacijski službenici imaju posebne studije probacije organizirane na više razina. U Irskoj, Bugarskoj i Češkoj zahtijeva se, primjerice, razina magistra, odnosno završenog diplomskog studija. Pri tome, u Češkoj i Engleskoj i Walesu u obavljanju probacijski poslova sve češće sudjeluju probacijski asistenti koji posjeduju srednju stručnu spremu. Ovakav trend povezan je sa smanjivanjem troškova, budući da su njihove plaće nešto niže.

Posebne se primjedbe upućuju probacijskom studiju u Engleskoj i Walesu s obzirom da polaznici stječu diplomu nakon samo dvogodišnjeg obrazovanja, pri 
čemu im to može biti i prva i jedina diploma. Ističe se da je dvogodišnji studij prekratak za usvajanje svih potrebnih profesionalnih kompetencija s obzirom da se u njega mogu uključiti i osobe koje nemaju neku raniju sveučilišnu diplomu (Ward i Spencer, 1994.). Napominje se kako druga pomažuća zanimanja (primjerice, medicinske sestre) teže sve višoj razini edukacije kako bi stručnjaci imali širinu u znanju, specijalizaciju u području, kritičko i reflektivno razmišljanje što ih u svojoj ukupnosti čini kvalificiranim stručnjacima, dok se obrazovanje probacijskih službenika počinje kretati u suprotnom smjeru. Autori navode kako se stječe dojam da se zanemaruje činjenica da probacijski službenici rade s vrlo teškim i složenim slučajevima, provode zahtjevan posao procjene rizika, rade s ljudima koji imaju poremećaje mentalnog zdravlja i s ljudima koji imaju kaotične živote narušene cijelim rasponom materijalnih i emocionalnih deprivacija, a da pri tome donose $\mathrm{i}$ važne odluke koje se reflektiraju na njihove živote. Stoga se u okviru ovog studija, u novije vrijeme, pokušalo postići konsenzus o potrebi postizanja sinteze između svakodnevnih praktičnih vještina i nužnosti teorije i etičkog okvira, na način da se kombinira praktično učenje na radnom mjestu sa sveučilišnim programima. Dakle, zamišljeno je da se ovaj studij provodi kroz dva glavna modela: (1) učenje u radnom okruženju (eng. practice-based learning) (pri čemu se naglašava važnost da novim službenicima bar pola radnog vremena bude osigurano za učenje te postojanja stručnjaka koji će se posebno baviti edukacijom novih službenika) i (2) akademsko učenje (eng. university-based learning) (Davies, 2011.)

Međutim, moguće je zaključiti kako protekom vremena, te pod utjecajem gospodarske krize u Engleskoj i Walesu, ipak sve više slabi uključenost sveučilišta u obrazovanje probacijskih službenika. Izbor sveučilišta za akademsko obrazovanje probacijskih službenika odvija se putem javnih natječaja. Dok je 2009. godine u edukaciju probacijskih službenika bilo uključeno 5 sveučilišta, 2011. godine bila su uključena svega 3, čini se prvenstveno s ciljem smanjenja financijskih troškova (Davies i Durrance, 2009.; Davies, 2011.). Isti autori posebno su analizirali pomak edukacije probacijskih službenika s usvajanja znanja prema usvajanju vještina, tj. pomak od edukacije prema treninzima. Ističu kako se, za razliku od sveobuhvatnog obrazovanja koje širi horizonte, potiče profesionalnu znatiželju i maštu, promiče intelektualno samopouzdanje i kapacitet za samousmjeravajuće učenje, olakšava pisano i verbalno izražavanje, novim načinom obrazovanja gube teorijski i edukacijski/pedagoški temelji, dolazi do rascjepkanosti znanja, a da visoko birokratski sustav učenja vještina može ometati i/ili sprječavati reflektivno učenje. Javlja se tendencija prema njegovanju mehaničkog, na vještine usmjerenog učenja (eng. skill-based approach), sukladno menadžerijalističkom pristupu praksi (eng. managerial approach), u odnosu na integrirani profesionalni model. Usporedno s aktualno uočenim tendencijama ušteda, akademsko se učenje sve više odvija kroz

\section{4 članci}


elektroničko učenje (e-učenje ili engl. e-learning). Izvori znanja sve su češće pisani materijali objavljeni na internetu s ugrađenim linkovima prema relevantnim internet stranicama i domenama, sučeljima za raspravu (forumima), video materijalima i video konferencijama te drugim sadržajima elektronički dostupnim (eng. blended-learning approach) (Davies i Durrance, 2009.). Ovakvom načinu učenja Davies (2011.) upućuje sljedeće primjedbe:

a) radi se o izoliranom načinu učenja, dok istraživanja pokazuju kako je dinamika fizičke prisutnosti značajno povezana s motivacijom i inspiracijom

b) učenje je težak posao pri čemu novi koncepti mogu biti uznemirujući, samopouzdanje može fluktuirati, povratnu informaciju je ponekad teško prihvatiti, dok istraživanja pokazuju kako se kroz neposredni kontakt u procesu učenja jača osjećaj podrške, pri čemu je posebno važna podrška drugih osoba u okviru grupe čiji se članovi redovito sastaju

c) praktične vještine najbolje se usvajaju učenjem licem u lice

d) izostaje neposrednost rasprave i argumentiranja uz njihov potencijal da se otvore nove perspektive, razvijaju koncepti i kreira intelektualna energija.

E-učenje sve je više zastupljeno i u okviru naknadnog stručnog usavršavanja službenika. U pokrajini West Midlands u Velikoj Britaniji 1995. godine razvijen je informacijski alat Lotus Notes, s ciljem osiguravanja različitih znanja i informacija probacijskim službenicima. Istraživanje je pokazalo da samo $12 \%$ praktičara zaista konzultira takve baze podataka, u usporedbi s $69 \%$ koji redovito konzultiraju svoje kolege i usmjereni su na neposredan kontakt (Sawbridge, 2002.).

Istraživanje Davis i Durrance (2009.) u Engleskoj i Walesu koje je obuhvatilo nove, mlade zaposlenike probacije pod mentorstvom, stručnjake za obrazovanje u radnom okruženju i sveučilišne profesore pokazalo je kako sve tri skupine izričito naglašavaju vrijednost jasne organizacijske podrške učenju. Stručnjaci ističu svoju borbu za promicanje i obranu akademskog okruženja jer se nove probacijske službenike više doživljava kao operativni resurs, nego kao službenike u procesu učenja posla. Novi probacijski službenici istaknuli su da su iskusniji probacijski službenici često prezaposleni za stvarni doprinos njihovom učenju i da ih ponajviše vide kao smetnju. Identificirali su nekoliko obrazovnih aktivnosti za koje smatraju da djeluju podržavajuće:

- strukturirane radionice »licem u lice«

- seminari na sveučilištu

- stručnjaci kao gosti predavači

- posjeti zatvorima i druge prilike za razvoj šireg razumijevanja kaznenopravnog sustava i s njim povezanih područja. 
lako vezano uz e-učenje napominju određene koristi kao što su lak pristup radovima i ključnim mrežnim stranicama, mogućnost učenja u proizvoljno vrijeme, lakše uključivanje povučenijih osoba u rasprave, ipak veći dio službenika ističe da im je e-učenje od male ili nikakve pomoći.

O Neill (2009.) naglašava značaj kontinuiranog profesionalnog razvoja, odnosno cjeloživotnog učenja probacijskog osoblja u svrhu očuvanja visoko educirane i osposobljene radne snage te kontinuiranog poboljšanja kvalitete usluga u okruženju koje zahtijeva visoke razine kompetencije. Stoga autor upućuje kako je neophodno razvijati edukacije i treninge koji omogućuju: (1) razvoj praktičara iznad početnih razina kompetencija u okviru specijalističkih područja probacijske prakse, (2) promoviranje međustrukovnog učenja i multi-profesionalne prakse te (3) razvoj vještina vođenje i rukovođenja.

\section{OBRAZOVANJE PROBACIJSKIH SLUŽBENIKA U HRVATSKOJ}

Probacijske poslove u Hrvatskoj mogu obavljati probacijski službenici koji su obrazovani u području socijalne pedagogije, socijalnog rada, psihologije, pravnih znanosti, a iznimno i drugih društvenih i humanističkih znanosti (Zakon o probaciji, 2012., čl. 4, st. 3). U okviru probacijske službe danas uglavnom rade socijalni radnici, socijalni pedagozi, psiholozi i pravnici.

lako različiti po svojoj strukturi, sadržaju, pa konačno i stečenom zanimanju po završetku studija, postoje sličnosti zbog kojih je opravdano zapošljavanje upravo ovih struka u probacijskoj službi. Studiji socijalne pedagogije, socijalnog rada i psihologije zahvaćaju komponentu zajedničkih kompetencija koje je moguće nazvati kompetencijama za psihosocijalni rad, a odnose se na pomaganje ljudima za nošenje s različitim osobnim i životnim poteškoćama (Huić, Ricijaš i Branica, 2010.). Stoga ove struke možemo nazvati pomažućim profesijama. Studij prava razlikuje se po svojoj snažnoj usmjerenosti na legislativu, što je također važna komponenta rada u okviru pravosuđa, ali ne predstavlja pomažuću profesiju u psihosocijalnom kontekstu. Pri tome studijski program socijalne pedagogije najveći naglasak stavlja na kompetencije za rad s počiniteljima kaznenih djela, potom ga prati studij socijalnog rada koji zahvaća ovo područje u širem kontekstu socijalnih problema, dok se studij psihologije najmanje bavi specifično ovom populacijom (Ricijaš, Huić i Branica, 2006.).

Zanimljivim se čini istaknuti da su u okviru studija socijalne pedagogije kolegiji Penološka rehabilitacija I i II uključivali obrazovanje studenata o inozemnim iskustvima na provođenju alternativnih sankcija, u vrijeme kada se alternativne sankcije prema punoljetnim počiniteljima kaznenih djela u Hrvatskoj još nisu ni

\section{6 Članci}


počele provoditi (Mikšaj-Todorović i Buđanovac, 1997.). Važno je napomenuti također da socijalni pedagozi u svojem preddiplomskom studiju danas slušaju i polažu poseban kolegij pod nazivom Teorija i metodika probacije, a koji se ciljano bavi izvaninstitucionalnim tretmanom punoljetnih počinitelja kaznenih djela, kao i druge predmete iz ovog područja (primjerice Kriminologija, Penologija, Penološka rehabilitacija, Penološka psihologija i slično). U okviru studija socijalnog rada, uz druge kolegije važne za obavljanje probacijskih poslova (kao što su Kriminologija, Socijalni rad u penalnoj ustanovi, Alternativne mjere prema počiniteljima kaznenih djela u zajednici, Prevencija delinkvencije i resocijalizacija osoba delinkventnog ponašanja kroz rad u zajednici itd.), kolegij Socijalni rad u organizaciji zajednice nudi studentima IV. godine i mogućnost terenske stručne prakse u probacijskim uredima, stjecanje neposrednog iskustva i uvida u probacijski rad uz mentorstvo probacijskog službenika. Nakon početka rada hrvatske probacijske službe, preciznije početkom ljetnoga semestra akademske 2012./2013. godine, Filozofski fakultet u Splitu, u suradnji s još tri fakulteta Sveučilišta u Splitu: Pravnim, Medicinskim i Ekonomskim, pokrenuo je prvi interdisciplinarni poslijediplomski specijalistički studij pod nazivom Probacijski tretman. Studij traje tri semestra, a njime će se stjecati akademski naziv »sveučilišni/a specijalist/ica probacijskog tretmana«. S obzirom na navedeno, možemo zaključiti da na hrvatskim sveučilištima postoji interes za probaciju.

Pravilnikom o načinu obavljanja probacijskih poslova (2012., čl. 36 i 37; u daljnjem tekstu Pravilnik) propisano je provođenje uvodnih, vježbeničkih i prilagodbenih programa izobrazbe, namijenjenih vježbenicima, novoprimljenim službenicima na probnom radu i volonterima koji pomažu u izvršavanju probacijskih poslova. Uz ove programe, propisano je provođenje i specijaliziranih programa usmjerenih na stjecanje dodatnih, specifičnih znanja i vještina potrebnih za jačanje profesionalne osposobljenosti i učinkovitosti u obavljanju probacijskih poslova. Sukladno Pravilniku, specijalizirani programi obuhvaćaju edukacije iz sljedećih područja:

- provođenje sankcija i mjera u zajednici

- metode procjena osoba uključenih u probaciju

- motivacijski intervju

- $\quad$ rad sa specifičnim skupinama osuđenika (nasilni počinitelji, ovisnici, počinitelji seksualnih delikata itd.)

- znanja iz kriminologije i penologije

- druga relevantna područja za obavljanje probacijskih poslova.

Vezano uz obrazovanje probacijskih službenika u Hrvatskoj, važno je imati u vidu da je hrvatska probacijska služba osnovana tek prije nekoliko godina. O obavljanju probacijskih poslova nekoliko službenika (tada u okviru zatvorskog sustava) 
počelo se educirati već tijekom procesa ustrojavanja hrvatske probacijske službe. Naime, Twinning light projekt Europske unije pod nazivom »Podrška razvoju probacijskog sustava u Hrvatskoj« (u okviru CARDS-a 2004. godine) koji se provodio od svibnja do prosinca 2007. godine uključivao je i upoznavanje s praksom i iskustvima probacijskih sustava u Europi (Kovčo Vukadin, Rajić i Balenović, 2009.). U okviru sljedećeg projekta pod nazivom »Tranzicijska podrška razvoju probacije u $\mathrm{RH}$ « koji se provodio od travnja 2008. do ožujka 2010. godine izrađena je prva verzija instrumenta procjene kriminogenih rizika i potreba počinitelja kaznenih djela, nakon čega je provedena i prva edukacija službenika (još uvijek službenika zatvorskog sustava) za primjenu instrumenta kod procjene zatvorenika predviđenih za uvjetni otpust (Kovčo Vukadin, Rajić i Balenović, 2009.; Kovčo Vukadin, Rajić i Maloić, 2011.).

U razdoblju pripreme obrazovanja prvih probacijskih službenika koja je potom i realizirana u okviru 2008 - EU projekta »Razvoj probacijskog sustava u Republici Hrvatskoj« (kroz Twinning projekt) koji se provodio od lipnja 2011. godine do ožujka 2013. godine intenzivno se promišljalo o nužnosti osnivanja Centra za izobrazbu probacijskog sustava. Osnovna bi zadaća centra bila osigurati profesionalnost, stručnost i kvalitetu obavljanja probacijskih poslova kroz provođenje različitih programa cjeloživotnog učenja, ali i programa edukacije volontera, pravnih osoba koje sudjeluju u izvršavanju probacijskih poslova (primjerice, kod rada za opće dobro) kao i svih stručnjaka uključenih u obavljanje tih poslova (iz centara za socijalnu skrb, centara za ovisnosti, klubova liječenih alkoholičara, zdravstvenih ustanova itd.). Od osnivanja takvog centra zasad se odustalo, moguće zbog gospodarske krize, kao i usporenog procesa zapošljavanja novih probacijskih službenika (Kovčo Vukadin, Rajić i Maloić, 2011.; Maloić, 2013.).

Prvu uvodnu edukaciju hrvatskih probacijskih službenika proveo je razvojni tim za ustrojavanje probacijske službe, tj. nekadašnji službenici zatvorskog sustava koji su po osnivanju Središnjeg ureda Uprave za probaciju iz zatvorskog prešli u probacijski sustav. Programom su obuhvaćene specifičnosti probacijskog rada kod izvršavanja uvjetne osude sa zaštitnim nadzorom i rada za opće dobro na slobodi, kod probacijskih poslova tijekom kaznenog postupka, kao i tijekom izvršavanja kazne zatvora i uvjetnog otpusta. Prva specijalizirana edukacija probacijskih službenika provedena je u okviru ranije spomenutog EU-IPA 2008 projekta. Sadržaj edukacije prvenstveno se temelji na paradigmi »što funkcionira«, te paradigmi prestanka činjenja kaznenih djela, a edukacija službenika obuhvatila je teme kao što su: uvod u probaciju, procjena kriminogenih rizika i potreba počinitelja kaznenih djela, izrada pojedinačnog programa i revizija, izrada izvješća, motivacijsko intervjuiranje, prosocijalno modeliranje, stilovi učenja, tehnike rješavanja problema, uvažavanje različitosti i pristup jednakih mogućnosti, upravljanje slučajem,

\section{8 članci}


a djelomice i rad s posebnim kategorijama počinitelja kaznenih djela (seksualni prijestupnici, ovisnici) i visokorizičnim počiniteljima. Kroz ovaj projekt provedena je i edukacija za rukovodeće službenike probacijske službe, uz sadržaje kao što su vođenje i upravljanje, upravljanje promjenama, mjerenje radnog opterećenja, donošenje odluka, upravljanje konfliktima, mobbing, podrška i stručnjačka supervizija probacijskih službenika, vođenje sastanaka, europski okvir za upravljanje kvalitetom (European Framework for Quality Management - EFQM). U okviru treninga trenera educirani su i stručnjaci probacijske službe čiji je zadatak educiranje novih probacijskih službenika o specifičnim praktičnim znanjima i vještinama vezanim uz obavljanje probacijskih poslova te njihovo kontinuirano stručno usavršavanje.

Možemo zaključiti kako hrvatski probacijski službenici zadovoljavaju kriterij posjedovanja barem preddiplomske sveučilišne diplome, koji se kao značajan ističe u inozemnoj literaturi (Durnescu i Stout, 2011.), a što potom predstavlja dobar temelj za njihovo daljnje obrazovanje. $U$ tom smjeru pozitivnim se ocjenjuje i činjenica da se naglasak stavlja na pomažuće struke, pri čemu se potom daljnje obrazovanje usmjerava u okviru uravnoteženog pristupa (Whetzel i sur., 2011.), usmjerenog na dugoročnu promjenu ponašanja počinitelja kaznenih djela u svrhu smanjenja povratništva i zaštite zajednice. Inicijalno obrazovanje probacijskih službenika u okviru ranije opisanog EU projekta provedeno je kroz strukturirane radionice »licem u lice«, što se ocjenjuje učinkovitim načinom obrazovanja probacijskih službenika (Davis i Durrance, 2009.). Obrazovni su sadržaji usmjereni na usvajanje vještina koje probacijskim službenicima omogućavaju rad u okviru prakse utemeljene na dokazima (Andrews i Bonta, 2010., prema Raynor i Ugwudike, 2013.), što je važno sa stajališta buduće učinkovitosti probacijske službe u smislu socijalne reintegracije počinitelja kaznenih djela, smanjenja kriminalnog povrata i zaštite zajednice. Pozitivnim svakako treba istaknuti da je u okviru projekta provedena $\mathrm{i}$ edukacija trenera, čime se osigurava mogućnost daljnjeg educiranja probacijskih službenika.

Ipak, s obzirom na iznesene sugestije integriranog pristupa obrazovanju probacijskih službenika (Knight i Stout, 2009.), inicijalnoj se edukaciji hrvatskih probacijskih službenika donekle može zamjeriti izostanak teorijske perspektive, prvenstveno kriminološke i penološke. Naime, evidentan je početni izostanak akademskog cjeloživotnog učenja, s obzirom da u inicijalno obrazovanje probacijskih službenika nije bila uključena akademska zajednica. $U$ suvremenoj se literaturi s druge strane upravo naglašava značaj uključivanja sveučilišta, u svrhu usvajanja šireg znanja koje omogućava stručno donošenje odluka i kritičku i reflektivnu primjenu vještina, a ne samo njihovu mehaničku primjenu (Knight i Stout, 2009.; Davies i Durrance, 2009.; Davis, 2011.; Skinner i Goldhill, 2013.). Nadalje, obrazovnim sadržajima samo su djelomice bila obuhvaćena specifična znanja i vještine potrebne za 
rad s različitim skupinama počinitelja kaznenih djela (seksualni delikti, obiteljsko nasilje, ovisnici i slično), dok se važnost specijaliziranih edukacija posebno ističe u okviru ranije navedenih Europskih probacijskih pravila. Obrazovni proces nije obuhvatio aktivnosti i sadržaje, kao što su, primjerice, posjete zatvorima ili predavanja gosta predavača, koji bi bili usmjereni na razvoj šireg razumijevanja kaznenopravnog sustava i s njima povezanih područja (Davis i Durrance, 2009.). S obzirom da se radi o nedavno osnovanoj probacijskoj službi, učenje u radnom okruženju koje se naglašava kao izuzetno važno (Davis, 2011.) nije bilo moguće provesti, budući da su svi probacijski službenici zaposleni i educirani otprilike u isto vrijeme. Ipak, za budućnost je važno zapamtiti da se u okviru inozemnih iskustava posebno naglašava značaj kontinuiranih treninga i vođenja na radnom mjestu jer rezultati istraživanja pokazuju malu primjenu naučenih vještina ukoliko se ono ne osigura (Joyce i Showers 2002., prema Lovenkamp i sur., 2012.). Važnim se čini spomenuti i da u okviru projekta nije otvorena mogućnosti e-učenja, koje ima niz nedostataka i ne može biti jedini oblik obrazovanja, ali ga određeni broj probacijskih službenika ipak ocjenjuje korisnim (Davis i Durrance, 2009.). Također, nije provedena sveobuhvatna evaluacija edukacije na način kako se to preporuča u literaturi, to jest na svim razinama (Sirdifield, Gardner i Booker, 2010.).

Kako su u osmišljavanju edukacija probacijskih službenika u Hrvatskoj prvenstveno sudjelovali engleski i češki stručnjaci, u daljnjem razvoju hrvatskog probacijskog kurikuluma svakako treba voditi računa i o iskustvima drugih zemalja. To ne znači ujedno i da se postojeći kurikulum ocjenjuje nezadovoljavajućim. Dapače, on je izrađen u okviru uravnoteženog pristupa probacijskom radu, a predavači su uglavnom bili iskusni probacijski stručnjaci, educirani o probacijskom radu i prije nedavnih velikih promjena koje su se dogodile u njihovim probacijskim sustavima (Maloić, 2013.), uz posjedovanje i drugih diploma, a ne samo probacijske dobivene nakon dvogodišnjeg studija. Također, vezano uz počinitelje kaznenih djela, Hrvatska ima dugu rehabilitacijsku tradiciju (Šimpraga i Vukota, 2010.), kojoj su se nastojali prilagoditi i inozemni stručnjaci.

Buduće obrazovanje probacijskih službenika, uz provjeru usvojenosti znanja i vještina od strane polaznika, svakako treba uključivati i evaluaciju na različitim razinama kao što je već ranije istaknuto u radu, uz obvezno uključivanje akademskih znanja. Kod planiranja je potrebno uzeti u obzir i prethodno znanje polaznika, kako sadržaj ne bi izazivao anksioznost zbog prevelike količine znanja odjednom kod osoba bez ranijih temelja, ili frustraciju zbog ponavljanja već stečenih znanja (Skinner i Goldhill, 2013.). Edukacija probacijskih službenika svakako treba uključivati i teorijski okvir koji će se povezati s probacijskom praksom. Svakako je preporučljiva kombinacija različitih oblika i modela učenja (predavanja, radionice, informacijske baze), međutim ipak s naglaskom na pristupu licem u lice i neposrednom

\section{0 članci}


vođenju/mentoriranju. Kao što ističe O Neill (2009.) vezano uz sve probacijske službe, i u Hrvatskoj će biti važno kontinuirano raditi na podizanju razina kompetencija probacijskih službenika, promovirati međustrukovno učenje, uz unaprjeđivanje vještina vođenja i rukovođenja. Kao prvi dobar primjer u tom smjeru možemo istaknuti suradnju probacijskog i zatvorskog sustava, u okviru koje je u prosincu 2013. godine organizirana posjeta svih probacijskih službenika kaznionicama i zatvorima, u svrhu omogućavanja uvida u specifičnost okruženja, način funkcioniranja kaznionica i zatvora i rad službenika zatvorskog sustava. Aktualno se naročito potrebnim čini daljnji razvoj programa obrazovanja probacijskih službenika vezan uz rad s posebnim kategorijama počinitelja kaznenih djela, kao što su seksualni prijestupnici i ovisnici. Naime, s porastom izvršavanja broja nadzora uvjetno otpuštenih osuđenika (tijekom 2012. godine provođeno je 9 nadzora, dok se na dan 6. prosinca 2013. godine provodi 652 nadzora), raste i složenost obilježja populacije s kojom rade hrvatski probacijski službenici, pa tako i broj počinitelja unutar pojedinih karakterističnih subgrupa.

\section{ZAKLJUČAK}

Iz prikazanog pregleda literature, možemo zaključiti u prilog raznolikosti razine i načina obrazovanja probacijskih službenika na europskom području, pri čemu bismo kao aktualne poteškoće u okviru inozemnih iskustava obrazovanja probacijskih službenika istaknuli sljedeće:

- smanjivanje sredstava predviđenih za obrazovanje probacijskih službenika, što dovodi do smanjivanja broja i kraćeg trajanja edukacija/treninga

- zapošljavanje osoba s nižom razinom obrazovanja, čiji je rad jeftiniji, a u svrhu smanjivanja troškova obavljanja probacijskih poslova

- slabljenje uključenosti sveučilišta u obrazovanje probacijskih službenika

- neuravnoteženi pomak edukacija probacijskih službenika s usvajanja znanja prema usvajanju vještina

- usmjerenost prema e-učenju kao »bržem« i jeftinijem načinu obrazovanja.

Vjerujemo kako će se osmišljavanjem i prihvaćanjem europskog probacijskog donekle prevladati postojeći problemi, međutim jasno je da se radi o složenom procesu koji će zahtijevati brojna usklađivanja i pregovore.

Okvirnu odluku Vijeća Europe 2008/947/PUP od 27. studenoga 2008. godine Hrvatska je u svoje zakonodavstvo implementirala Zakon o pravosudnoj suradnji u kaznenim stvarima s državama članicama Europske unije (Narodne novine, br. 91/10, 81/13, 124/13), a koji je stupio na snagu s danom pristupanja Hrvatske 
Europskoj uniji, to jest 1. srpnja 2013. godine. To znači da bi hrvatska probacijska služba trebala svakom počinitelju kaznenog djela državljaninu zemalja Europske unije, a koji će probacijsku sankciju ili mjeru izvršavati u Hrvatskoj, osigurati istu razinu usluge koju bi imao u svojoj državi ili u bilo kojoj drugoj članici Europske unije. U tom smjeru Hrvatska se svakako treba rukovoditi Europskim probacijskim pravilima, a time i pravilima navedenim ranije u ovom radu koja se odnose na izobrazbu probacijskih službenika. Do donošenja europskog probacijskog kurikuluma u budućnosti, a što očito neće biti ni brz ni lagan proces, preporučljivo bi bilo uvažavati ranije navedene ključne kompetencije koje je izdvojila Europska grupa za probacijski kurikulum.

Hrvatska probacijska služba ima inicijalno dobro temelje za edukaciju i stručno usavršavanje svojih službenika, koje će biti nužno dalje podržavati, razvijati i unaprjeđivati. Razumljivo je da nisu sve države uvijek u mogućnosti provoditi i vlastita istraživanja učinkovite prakse, stoga se suradnja s drugim državama čini od velike važnosti, kao i učenje na njihovom iskustvu, dok se provedu vlastita istraživanja o tome što funkcionira na specifičnom kulturalnom, institucionalnom i zakonskom okruženju. Dobar primjer kako se to može činiti je instrument procjene kriminogenih rizika i potreba »Sustav procjene počinitelja kaznenih djela« (SPP), koji je i izrađen temeljem inozemnih iskustava, a tek mu predstoji domaća validacija i daljnji razvoj (Ricijaš, 2010;; Maloić i Mažar, 2013.). S daljnjim razvojem instrumenta i nakon provedene inicijalne bit će nužno i dodatno kontinuirano obrazovanje probacijskih službenika, čemu će doprinijeti i očekivani daljnji razvoj instrumenata namijenjenih specifičnim skupinama počinitelja kaznenih djela ili procjeni prikladnosti za određeni program koji već u inozemstvu postoje (Witt i Schneider, 2005.; Rettenberger i Eher, 2006.; Bullock, 2010.).

S obzirom na složenost obilježja probacijske populacije, autori ovog rada podržavaju tezu da je, osim propisanih standarda, procedura i alata, probacijskim službenicima potrebno i sveobuhvatno znanje i kritička svijest koje njihov posao zahtijeva od njih, a sve to s obzirom na složenost etiologije činjenja kaznenih djela, jedinstvenost osoba uključenih u probaciju i značaj etičkih pitanja s kojima se susreću. S tog gledišta, uključenost u akademsko obrazovanja i u naknadni treninzi usavršavanja svakako su poželjni i nužni, a očito je da interes hrvatskih sveučilišta postoji. Kao što ističu Skinner i Goldhill (2013.), profesije sa sličnim ovlastima pozitivnog i negativnog utjecaja na ljude kao što su liječnici, profesori, odvjetnici i socijalni radnici imaju duge kvalifikacijske okvire i striktne etičke kodekse kako bi se zaštitili klijenti, tako da rad s počiniteljima kaznenih djela ne bi smio biti iznimka.

Dakle, autori ovog rada podržavaju stav da bi probacijske službe, pa tako i hrvatska probacijska služba, trebale biti učeće organizacije, s naglaskom na paradigmu cjeloživotnog učenja, koje prepoznaju da je vrijeme uloženo u učenje dobro

\section{2 članci}


i korisno utrošeno vrijeme. S tim u vidu, hrvatska bi probacijska služba poseban naglasak trebala staviti na cjeloživotno obrazovanje probacijskih službenika, pri čemu je ključno:

- osmišljavanje, razvoj i financiranje programa cjeloživotnog obrazovanja probacijskih službenika namijenjenih usavršavanju tijekom rada (stjecanje potrebnih teorijskih znanja i praktičnih vještina)

- motiviranje, usmjeravanje i poticanje probacijskih službenika na aktivno i konstruktivno sudjelovanje u tim programima

- omogućavanje i praćenje primjene naučenog na radnom mjestu, u neposrednom radu s počiniteljima kaznenih djela, posebno kod novih i nedovoljno iskusnih službenika

- usvajanje temeljnih kompetencija za rad s počiniteljima kaznenih djela u okviru koncepta tzv. osnovne korekcijske prakse, uz kontinuirani razvoj kompetencija potrebnih za provođenje zaštitnog nadzora u okviru paradigme "što funkcionira« i desistance paradigme

- provođenje programa kontaktima »licem u lice«, grupni rad, promoviranje međustrukovnog učenja, uključenost sveučilišta i drugih institucija u okviru ili izvan okvira kaznenopravnog sustava, a koje sudjeluju u izvršavanju probacijskih poslova

- stvaranje preduvjeta za e-učenje, ali samo kao jedne od mogućnosti koje će probacijski službenici imati na raspolaganju.

Važan je zadatak svake probacijske službe kreiranje vremena i prostora za učenje, a obrazovanje kao strategija treba biti zastupano na najvišim razinama organizacije. U vrijeme gospodarske krize kada se, uz manjak osoblja i druge organizacijske poteškoće, uočavaju tendencije k smanjivanju razine obrazovanja i ograničavanju obrazovnih sadržaja, potrebu za obrazovanjem i stručnim usavršavanjem potrebno je dodatno naglašavati i zastupati (Davies i Durrance, 2009.).

LITERATURA

1. Bonta, J. \& Andrews, D. (2007). Risk-need-responsitivity model from offender assessment and rehabilitation 2007-2006. Ottawa: Public Safety Canada.

2. Bonta, J., Rugge, T., Scott, T., Bourgon, G. \& Yessine, A. K. (2008). Exploring the black box of community supervision. Journal of Offender Rehabilitation, 47 (3), 248-270.

3. Bracken, D. (2003). Skills and knowledge for contemporary probation practice. Probation Journal, 50 (2), 101-114. 
4. Brooker, C. \& Sirdifield, C. (2009). An evaluation of mental health awareness training for probation staff. Lincoln: University of Lincoln.

5. Bullock, K. (2010). The construction and interpretation of risk management technologies in contemporary probation practice. British Journal of Criminology, 51 (1), 120-135.

6. Burke, P., Gelb, A. \& Horowitz, J. (2007). When offenders break the rules, smart responses to parole and probation violations. Public Safety Brief, 3. Philadelphia: Pew's Center on the State.

7. Byrne, J. M. \& Taxman, F. S. (2006). Crime control strategies and community change - Reframing the surveillance vs. treatment Ddebate. Federal Probation, 70 (1), Preuzeto s: http://www.uscourts.gov/viewer.aspx?doc=/uscourts/ FederalCourts/PPS/Fedprob/2006-06/index.html (07.06.2013).

8. Cox, S. M., Bantley, K. \& Roscoe, T. (2005). Evaluation of the court support services division's probation transition program and technical violation unit. New Britain: Central Connecticut State University.

9. Cox, S. M., Bantley, K. \& Newton, S. (2010). The final report of the evaluation of the court support services division's technical violations units. New Britain: Central Connecticut State University.

10. Davies, K. (2011). Work-based distance learning for probation practise: Doing the job properly. Probation Journal, 58 (1), 68-73.

11. Davies, K. \& Durrance, P. (2009). Probation training:The experience of teachers and learners. Social Work Education, 28 (2), 204-221.

12. Dodig, D. \& Ricijaš, N. (2011). Profesionalne kompetencije socijalnih pedagoga. U: Poldrugač, Z., Bouillet, D. \& Ricijaš, N. (ur.), Socijalna pedagogija znanost, profesija i praksa u Hrvatskoj. Zagreb: Edukacijsko-rehabilitacijski fakultet Sveučilišta u Zagrebu

13. Doran, P. \& Cooper, L. (2008). Social work: The core qualification of probation officers in Northern Ireland. Irish Probation Journal, 5, 23-35.

14. Dowden, C. \& Andrews, D. A. (2004). The importance of staff practice in delivering effective correctional treatment: A meta-analytic review of core correctional practice. International Journal of Offender Therapy and Comparative Criminology, 48 (2), 203-214.

15. Durnescu, I. \& Stout, B. (2011). A European approach to probation training: An investigation into the competencies required. Probation Journal, 58 (4), 395-405.

16. Durnescu, I., Enengl, C. \& Grafl, C. (2013). Experiencing supervision. In: McNeill, F. \& Beyens, K. (eds.), Offender supervision in Europe. Basingstoke: Palgrawe Macmillan, 19-50.

17. Elliot, W. N. (2002). Managing offender resistance to counseling: The $» 3 R ' s »$. Probation Journal, 66 (3), 43-49. 
18. Falkin, G. P., Strauss, S. \& Bohen, T. (1999). Matching drug-involved probationers to appropriate drug interventions: A strategy for reducing recidivism. Federal Probation, 63 (1), 3-8.

19. Hanser, R. D. (2010). Community corrections. Thousand Oaks: SAGE Publications, Inc.

20. Herzog-Evans, M. (2011). Desisting in France: What probation officers know and do: A first approach. European Journal of Probation, 3 (2), 29-46.

21. Herzog-Evans, M. (2012). Non-compliance in France: A human approach and a hair splitting legal system. European Journal of Probation, 4 (1), 46-62.

22. Huić, A., Ricijaš, N. \& Branica, V. (2010). Kako definirati i mjeriti kompetencije studenata - validacija Skale percipirane kompetentnosti za psihosocijalni rad. Ljetopis socijalnog rada, 17 (2), 195-221.

23. Hussey, J. (2012). Reoffending - A prectitioner's guide to working with offenders and offending behaviour in the criminal justice system. Birmingham: Bennion Kearny Limited.

24. Jenuwine, M. J., Simmons, R. \& Swies, E. (2003). Community supervision of sex offenders - Integrating probation and clinical treatment. Federal Probation, 67 (3), 20-27.

25. Jones, M. \& Kerbs, J. J. (2007). Probation and parole officers and discretionary decision-making: Responce to technical and criminal violations? Federal Probation, 71 (1). Preuzeto s: http://www.uscourts.gov/FederalCourts/ Probation PretrialService s/FederalProbationJournal.aspx (03.01.2014.).

26. Kalmthout, A. \& Durnescu, I. (2008). Probation in Europe. Nijmegen: Wolf Legal Publishers.

27. Knight, C. \& Stout, B. (2009). Probation and offender manager training: An argument for an integrated approach. Probation Journal, 56 (3), 269-283.

28. Kovčo Vukadin, I., Rajić, S. \& Balenović, M. (2009). Uspostava probacijskog sustava - novi izazov za Hrvatsku? Hrvatski ljetopis za kazneno pravo i praksu, $16(2), 711-751$.

29. Kovčo Vukadin, l., Rajić, S. \& Maloić, S. (2011). Izazovi u izgradnji probacijskog sustava u Republici Hrvatskoj. Hrvatski ljetopis za kazneno pravo i praksu, 18 (2), 717-735.

30. Latessa, E. J. (1996). The Supervision of Persons with Mental Illness on Probation Supervision. In: Lurigio, A. J. (eds.), Community corrections in America: New directions and sounder investments for persons with mental illness and codisorders. Seattle: National Coalition for Mental and Substance Abuse Health Care in the Justice System, 40-59.

31. Latessa, E. J. (2006). What works in reducing recidivism? University of St. Thomas Law Journal, 3 (3), 521-535. 
32. Lovenkamp, C. T., Holsinger, A. M., Flores, A. W., Koutsenok, I. \& Pearl, N. (2013). Changing probation officer attitudes: Training experience, motivation, and knowledge. Federal Probation, 77 (2). Preuzeto s: http://www.uscourts. gov/ Federal Courts/ProbationPretrialServices/FederalProbation Journal.aspx (30.12.2013.).

33. Lovenkamp, M. S., Robinson, C. R., Koustenok, I., Lovenkamp, C. T. \& Pearl, N. (2012). The importance of coaching: A brief survey of probation officers. Federal Probation, 76 (2). Preuzeto s: http://www.uscourts.gov/FederalCourts/ Probation PretrialService s/FederalProbationJournal.aspx (02.01.2014.).

34. MacDonald, S. S. \& Baroody-Hart, C. (1999). Communication between probation officers and judges: An innovative model. Federal Probation, 63 (1), 42-50.

35. Maloić, S. (2013). Menadžment u organizacijama kaznenopravnog sustava vrijeme promjena. Praktični menadžment, 4 (2), 50-59.

36. Maloić, S. \& Mažar, A. (2013). Pristupi i tehnike rada s ovisnicima u probaciji. Kriminologija i socijalna integracija, u postupku objave.

37. Maloić, S., Mažar, A. \& Jandrić Nišević, A. (2013). Zlouporaba droga - pristupi, paradigme i načini rada u okviru probacije. Ljetopis socijalnog rada, 20 (3), 481-508.

38. Maloić, S. \& Rajić, S. (2012). Potreba i značaj razvoja suradnje probacijskog sustava i sustava socijalne skrbi u RH. Ljetopis socijalnog rada, 9 (1), 29-52.

39. Mikšaj-Todorović, Lj. \& Buđanovac, A. (1997). Edukacija studenata socijalne pedagogije za rad na rehabilitaciji osuđenih u penalnom sustavu. Kriminologija i socijalna integracija, 5 (1-2), 89-93.

40. Morran, D. (2008). Firing up and burning out: The personal and professional impact of working in domestic violence offender programmes. Probation Journal, 55 (2), 139-152.

41. Nellis, M. (1992). Probation training after CJA 1991: The need for debate. Probation Journal, 39 (2), 87-91.

42. Norton, S. (2012). Motivational interviewing: An appropriate model for engaging clients with drug abuse problems in the probation service. Irish Probation Journal, 9, 132-141.

43. Oleson, J. C., VanBenschoten, S. W., Robinson, C. R. \& Lovenkamp, C. T. (2011). Training to see risk: Measuring the accuracy of clinical and actuarial risk assessments among federal probation officers. Federal Probation, 75 (2). Preuzeto s: http://www.uscourts.gov/FederalCourts/ProbationPretrialServices/Federal Probation Journal.aspx (04.01.2014.).

44. O Neill, N. (2009). Post-qualifying Training in the PBNI. Irish Probation Journal, 6, 23-31. 
45. Persson, A. \& Svensson, K. (2011). Signs of resistance? Swedish probation officers' attitudes towards risk assessments. European Journal of Probation, 3 (3), 95-107.

46. Raynor, P. \& Ugwudike, P. (2013). Skills and training in British probation: A tale of neglect and possible revival. Federal Probation, 77 (2). Preuzeto s: http:// www.uscourts.gov/FederalCourts/ ProbationPretrialServices/Federal Probation Journal.aspx (06.01.2014.).

47. Raynor, P. \& Robinson, G. (2009). Why help offenders? Arguments for rehabilitation as a penal strategy. European Journal of Probation, 1 (1), 3-20.

48. Reddick, C. \& Chapin, D. (1999). Domestic violence: A probation officer's view. Perspectives, Spring, 18-22.

49. Rentzmann, W. (2008). Prison policy, prison regime and prisoners' rights in Denmark. In: Prison policy and prisoners' rights, proceedings of the colloquium of the IPPF, Stavern, Norway, 25-28 June 2008. Nijmegen: Wolf Legal Publishers.

50. Rettenberger, M. \& Eher, R. (2006). Actuarial assessment of sex offender recidivism risk: A validation of the German version of the Static-99'. Sexual Offender Treatment, 1 (3). Preuzeto s: http://www.sexual-offender-treatment. org/ issues.html (24.09.2013.).

51. Ricijaš, N. (2010). Instrumenti procjene kriminogenih rizika i potreba u probaciji. 3. hrvatski kongres socijalnih pedagoga s međunarodnim sudjelovanjem, 23.-25. travanj 2010. godine, Zagreb. Preuzeto s: http://husp.hr/ index.php/cro/Strucni-skupovi/3.-Kongres-socijalnih-pedagoga-s-medunarodnim-sudjelovanjem (03.04.2013.).

52. Ricijaš, N., Huić., A. \& Branica, V. (2006). Zadovoljstvo studijem i samoprocjena kompetentnosti studenata nekih pomagačkih profesija. Hrvatska revija za rehabilitacijska istraživanja, 42 (2), 51-68.

53. Ricijaš, N., Maloić, S. \& Rajić, S. (2012). Doživljaj posla probacijskih službenika u Hrvatskoj. 8. međunarodni znanstveni skup »/straživanja u edukacijskorehabilitacijskim znanostima«. Zagreb, Hrvatska, 27.-29.09.2012. Preuzeto s: http://bib.irb.hr/ prikazi-rad?\&rad=595975 (15.10.2013.).

54. Sawbridge, J. (2002). Information needs of probation staff. Probation Journal, 49 (4), 314-315.

55. Seiter, R. P. (2002). Prisoner reentry and the role of parole officers. Federal Probation, 66 (3), 50-54.

56. Senna, J. J. (1976). The need for professional education in probation and parole. Crime and Delinquency, 22 (1), 67-74.

57. Sieh, E. W. (2003). A theoretical basis for handling technical violations. Federal Probation, 67 (3), 28-32. 
58. Sirdifield, C., Gardner, M. \& Brooker, C. (2010). The importance of mental health awareness training in a European probation training curriculum. European Journal of Probation, 2 (2), 23-38.

59. Skinner, C. \& Goldhill, R. (2013). Changes in probation training in England and Wales: The probation qualification framework (PQF) Three Years On. European Journal of Probation, 5 (3), 41 - 55.

60. Slate, R. N., Roskes, E., Feldman, R. \& Baerga, M. (2003). Doing justice for mental illness and society: Federal probation and pretrial services officers as mental health specialists. Federal Probation, 67 (1), 13-19.

61. Slate, R. N., Feldman, R., Roskes, E. \& Baerga, M. (2004). Training federal probation officers as mental health specialists. Federal Probation 68 (3). Preuzeto s: http:// www.uscourts.gov/FederalCourts/ProbationPretrialServices/FederalProbation Journal. aspx (03.01.2014.).

62. Stout, B. \& Canton, R. (2010). Towards a European approach to probation education and training. British Journal of Community Justice, 8 (2), 57-68.

63. Subramanian, R. \& Shames, A. (2013). Sentencing and prison practices in Germany and the Netherlands: Implications for the United States. New York: Center on Sentencing and Corrections, Vera Institute of Justice.

64. Šimpraga, D. \& Vukota, Lj. (2010). Probni projekt Uvjetni otpust zatvorenika. Hrvatski ljetopis za kazneno pravo i praksu, 17 (2), 813-817.

65. Torres, S. \& Latta, R. (2000). Training the substance abuse specialist. Federal Probation, 64 (2), 52-57.

66. Trotter, C. (1996). The impact of different supervision practices in community corrections: Cause for optimism. Australian and New Zealand Journal of Criminology, 29 (1), 29-46.

67. Trotter, C. (2006). Working with involuntary clients: A guide to practice. London: Sage Publications Ltd.

68. Zakon o probaciji (2009). Narodne novine, 153/2009.

69. Zakon o probaciji (2012). Narodne novine, 143/2012.

70. Pravilnik o načinu obavljanja probacijskih poslova (2012). Narodne novine, 029/2013.

71. Walters, S. T., Clark, M. D., Gingerich, R. \& Meltzer, M. L. (2007). A guide for probation and parole: Motivating offenders to change. Washington: U.S. Department of Justice.

72. Ward, D. \& Spencer, J. (1994). The future of probation qualifying training. Probation Journal, 41 (2), 95-98.

73. Whetzel, J., Paparozzi, M., Alexander, M. \& Lovenkamp, C. T. (2011). Goodbye to a worn-out dichotomy: Law enforcement, social work, and a balanced approach (A survey of federal probation officer attitudes). Federal Probation, 75(2). Preuzeto s: http://www.uscourts.gov/FederalCourts/ ProbationPretrialServices/Federal Probation Journal.aspx (07.01.2014.). 
74. Williams, T. H. (2007). What works? Evidence-based practices in parole and probation. Journal of Community Corrections, 16 (4), 5-7.

75. Witt, P. H. \& Schneider, J. (2005). Managing sex offenders by assessing dynamic risk factors. Sex Offender Law Report, 6 (4), 49-64. 
Ljetopis socijalnog rada 2014., 21 (3), 511-540 str.

\section{Snježana Maloić}

Sector for Probation

Directorate for criminal law and probation

Ministry of Justice

Neven Ricijaš

Faculty of Education and Rehabilitation Sciences

University of Zagreb

\section{COMPETENCIES AND PROFESSIONAL DEVELOPMENT OF PROBATION OFFICERS}

\section{SUMMARY}

Probation officers are a relatively new profession in Croatia. This tradition has been present for almost 100 years in the Western countries, which therefore have considerable experience in successful and unsuccessful educational policies for probation officers, which in turn makes a good starting point for learning about the Croatian probation system. The aim of this paper is to analyse and investigate the levels and methods for training probation officers in Europe and the basic competences required for their work; explore current difficulties in training probation officers on the basis of international experiences, analyse the elements of training of probation officers in Croatia so far and present guidelines for the life-long learning of Croatian probation officers. The level of education and additional training directly affects the quality of work of probation officers, and it indirectly influences their attitudes, beliefs and approach towards perpetrators, and generally, the quality of work of the probation service as a whole. The authors have concluded that, in comparison with European experiences, Croatian probation officers at the moment have a satisfactory level of initial competences and training in the context of lifelong learning, and emphasized the importance of maintaining these practices, especially during the economic crisis.

Key words: probation, probation officers, competences, education, life-long learning. 